\title{
Does an Islamic Finance Industry Need a Unification of Standards? A Qualitative Discussion
}

\author{
Azhar Mohamad, and Aghilasse Kashi \\ Department of Finance, Kulliyyah of Economics and Management Sciences, \\ International Islamic University Malaysia, Kuala Lumpur, Malaysia \\ m.azhar@iium.edu.my;dr@azharmohamad.asia;aghiles.hira@gmail.com
}

\begin{abstract}
The two main problems faced by the Islamic finance industry in Muslim countries are that the markets are fragmented, which gives rise to different governing standards, and that the markets' growth is very much region-centric. In this article, using a qualitative approach, we identify the obstacles facing the industry in its quest to unify the differences and implement a uniform standard. We argue that if Malaysia's Islamic finance industry is to become a leader in the global Islamic finance industry, a key policy must be to reduce the gaps in Islamic finance practices between countries by adopting unified standards. Unifying standards could enable Muslim countries to accrue greater benefits from the globalisation of the Islamic financial sector and attract more foreign direct investment and portfolio equity flows. It could also enable greater integration of Islamic financial markets, increase diversification opportunities and expand the set of available financial instruments.
\end{abstract}

\section{Keywords}

standards - Islamic finance - qualitative approach - regulation

$\mathbf{1}$

\section{Introduction}

If the Islamic finance industry is to grow and develop, the market must diversify. Diversification and an increase in the volume of transactions can be achieved through increased foreign participation in Islamic finance markets. This will require an active and well-regulated trading platform between 
countries to allow capital flows across a wide range of shari'a-compliant instruments. However, the absence of standardised benchmark documents and procedures across countries at present hinders the efficiency of cross-border transactions. ${ }^{1,2}$ The documents and contracts used for Islamic financial instruments must be consolidated.

Currently, differences between markets pose a significant challenge for cross-border transactions. Across the countries that practice Islamic finance, the legal, regulatory and tax frameworks and standards require consolidation. The existing differences between such frameworks and standards is one of the main reasons for the fragmented nature of Islamic financial markets globally. In addition, the disparity in regulatory frameworks across regions results in added costs and inefficiencies, which can make Islamic finance less economical than conventional finance.

Another problem that arises when each jurisdiction has its own regulations (and when some jurisdictions do not even have specific regulations for Islamic finance) is the opportunity for regulatory arbitrage. ${ }^{3}$ An increase in international transactions risks exposing jurisdictions to sub-par Islamic finance instruments from jurisdictions that have weak or no regulation in this area. Thus, the internationalisation of Islamic finance markets necessitates the establishment of uniform, harmonised and rigorous regulatory standards.

Achieving global harmonisation in the interpretation of sharia principles is one of the major challenges facing the industry. A recent study by the International Shari'ah Research Academy for Islamic Finance (ISRA) finds that the differences in sharica rulings between Asian countries and the countries of the Gulf Cooperation Council (GCC) are 54.3\%. ${ }^{4}$ If these differences are not addressed effectively, they will likely confuse the public and make it less likely that Muslim customers accept Islamic financial products. In addition, without further unification across regions, the industry's efforts to expand its operations across borders and achieve growth may suffer. Progress in this direction is

1 M. Alwosabi, Regulatory Issues of Islamic Banking and Finance, unpublished Working Paper, Department of Economics and Finance, College of Business Administration, University of Bahrain, Isa Town, 2009.

2 W.N. Azmi, Creating an Effective and Efficient Regulatory Framework for the Islamic Capital Market, Working Paper Series 010, Kuala Lumpur Business School, 2007.

3 W.A. Ghoul, 'The standardization debate in Islamic finance: A case study', in 8th International Conference on Islamic Economics and Finance (Qatar, 2011).

4 A. Shaharuddin, M.A. Mas'ad, Y.H.M. Safian, Z. Shafii, A.Z. Salleh, M.H. Alias, J.A. Seman, M.A. Laldin \& M.F.A. Khir, 'Fatwas on Islamic capital markets: A comparative study between Malaysia and Gulf Cooperation Council (GCC) countries', ISRA Research Papers 40 (2012): $1-36$. 
necessary if the Islamic finance industry is to be globalised through increased cross-border transactions.

Differences in the validity of products between countries may expose Islamic financial institutions (IFIs) to greater international risks. In addition, the lack of standardisation may prevent investors from being aware of the exact risks they are assuming when they invest, increasing the costs of investment. ${ }^{5}$ Unifying standards could rectify these issues, as well as provide the benefit of increased cross-border marketability for IFIs.

This article provides some insight into an important issue currently facing the growing Islamic finance industry. Specifically, it looks at the unique challenges faced in developing an appropriate global regulatory framework and shari'a governance system for Islamic finance, and in addressing the problems arising due to differences in shari'a interpretations across jurisdictions. The article highlights important considerations in improving globally the direction, growth and integration of Islamic finance by considering the case for unifying standards and globally harmonising shari'a concepts. The article contributes to the existing body of knowledge by identifying pressing policy requirements needed to strengthen Islamic finance by closing the gaps and weaknesses that exist due to the heterogeneity in Islamic finance concepts and in sharía interpretations and practices.

We must determine not only the future direction that Islamic banking should take to achieve sustainable growth and development of the industry but also the role that any Muslim country can play in developing Islamic finance. In addition to the need for a uniform global regulatory and sharia framework, there is a more fundamental problem: whether the framework should be designed uniquely for Islamic finance. $6,7,8$ This article seeks to plug the gap in the areas in question by proposing that globally unified standards across legal, regulatory and governance frameworks, practices and documentation for Islamic financial transactions could strengthen the prospects for the sustainability, growth and global integration of the Islamic finance industry.

5 M.K. Hasan \& M.M. Chowdhury, 'Islamic banking regulations in light of Basel II', in Proceedings of the Fifth Harvard Research Forum on Islamic Finance (Cambridge: Harvard University, 2004).

6 M.K. Hasan \& M.F. Dicle, 'Basel II and regulatory framework for Islamic banks', Journal of Islamic Economics, Banking and Finance 1(1) (2005): 17-36.

7 A. Mirakhor \& N. Krichene, 'Recent crisis: Lessons for Islamic finance', in IFSB 2nd Public Lecture on Financial Policy and Stability (Kuala Lumpur, 2009).

8 N. Uddin, 'Comparative analysis of reporting practices of Islamic financial institutions (IFIs)', in 16 th International Business Research Conference (Dubai, 2012). 
The first objective of this article is to explore whether or not implementing unified regulatory, legal and governance standards is a necessary and viable solution to address the constraints facing the Islamic finance industry. The article's second objective is to identify the developments required to make a global platform for Islamic finance.

\section{$2 \quad$ Literature Review}

Many scholars have pointed to various issues associated with the observed heterogeneity in interpreting and applying Islamic finance concepts. The salient points and problems cited in past studies are outlined below.

Hassoune and Howaladar observe that despite a high growth rate, the Islamic finance industry remains fraught with diversity and heterogeneity, which has impeded the capacity of Islamic finance to improve its globalisation process. ${ }^{9}$ As a result, the authors note, most initiatives aimed at strengthening the Islamic finance industry have tended to remain country-specific despite the sustained efforts of cross-border organisations to bring about consistency.

The global expansion of Malaysia's Islamic finance industry also faces this constraint. As Azmi points out, although Malaysia already has a relatively robust regulatory structure, the main challenge is how to bring about convergence of regulatory structures across national borders. ${ }^{10}$

According to Muda and Jalil, past experiences have shown that some of Malaysia's Islamic financial products cannot be sold in the Middle East due to differences in juristic opinions. ${ }^{11}$ Even though Malaysian Islamic financial issuers and the Central Bank of Malaysia's Shariah Advisory Council have their own juristic arguments to support their standing in such cases, shari'a scholars in other regions may hold different views on the same issue. These differences are particularly crucial in relation to views concerning the sharia-compliance of an instrument. ${ }^{12}$ According to a study by the ISRA, Malaysian and GCC

9 A. Hassoune \& K. Howaladar, 'Islamic banks and sukuk: Growing fast, but still fragmented', Moody's Islamic Banking Report, April 2008, online at http://ddata.over-blog.com/ 4/-08/16/46//Islamic-banks-and-sukuk.pdf.

$10 \quad$ Azmi, supra note 2.

11 M. Muda \& A. Jalil, 'Islamic financial product development: Shariah analysis', in IIUM International Conference on Islamic Banking and Finance (IIciBF) (Kuala Lumpur, 2007).

12 S. Haron, 'Towards developing a successful Islamic financial system: A lesson from Malaysia', Working Paper Series oo3, unpublished manuscript, Kuala Lumpur Business School, 2004. 
countries differ $100 \%$ in the case of bai' al-inah (contract of credit sale), baic al-ma'dum (sale of non-available goods), da'wata'ajjal (cash discount), futures contracts and the ujrah (fee) for guarantees. Regarding preference shares and call warrants, there is an $80 \%$ difference between the two regions. Issues related to bai' al-wafa (a sale with a right of redemption) and bai' al-dayn (sale of debt for cash) also face significant disagreement ( $60 \%$ and $40 \%$ differences between the two regions respectively). ${ }^{13}$

Malaysia, for example, has a comparatively accommodating stance towards different schools of Islamic jurisprudence but faces a continuing debate on controversial products such as bai al-inah. Malaysia studies and applies these so-called controversial products as a temporary solution to aid the development and growth of Islamic banking and the Islamic capital markets. ${ }^{14}$ However, as Ghoul points out, this lack of consensus among scholars regarding the acceptability of specific features of Islamic financial products has hindered the growth of the Islamic banking industry. ${ }^{15}$ As Ghoul further notes, the lack of standardisation exposes the industry to 'shari'a arbitrage' because institutions and bankers may 'shop around' for favourable fatwas.

As Khalaf and Tett assert, a lack of standardised regulations, a lack of clarity in the legal framework and differences in the interpretation of the sharia hinder the sustainable growth of the Islamic finance industry. ${ }^{16}$ Additionally, Ghoul notes that the lack of progress in this regard is hampering innovation and creating loopholes that can be exploited by product designers. ${ }^{17}$ Shariaa restrictions in Islamic finance may encourage the design of products that work around such restrictions. One example is wa'ad-based (promise or unilateral agreement between parties to buy one currency against selling another currency at an agreed price for settlement at forward/future value date) by total return swaps that sidestep the constraints of derivative instruments. The resulting financial instruments will tend to conform to the letter but not the spirit of sharica law.

13 Shaharuddin et al., supra note 4.

14 Ibid.

15 Ghoul, supra note 3.

16 R. Khalaf \& G. Tett, 'Backwater sector moves into global mainstream', Financial Times, 23 May 2007, accessed online on 1 April 2014 at http://www.ft.com/intl/cms/s/o/aa477934 -o8ca-11dc-b11e-ooob5dfio621.html.

17 Ghoul, supra note 3. 
One of the areas that has received criticism is the use of concepts such as baic al-dayn. ${ }^{18}$ According to Malaysian scholars, the sale of Islamic bonds to third parties for cash at a lower price is allowable, but other scholars hold that the principle of selling debt to third parties is not permissible, because debt corresponds to money, and all exchanges must be equal in value. ${ }^{19,20}$ The Islamic Fiqh Academy of Jeddah has unanimously approved the prohibition of bai' al-dayn. Hence such differences in scholarly opinion about the shari'acompliance of Islamic finance concepts may impede the objective of increasing international transactions between Malaysian IF Is and those in other areas of the world.

As Alwosabi points out, shari'a has always been dynamic and open to different understandings and interpretations within the main framework of Islam. Likewise, Muslims may choose any of the different schools of Islamic jurisprudence (madhabs) as long as it does not contradict the main, well-known and well-documented Islamic principles and practices. ${ }^{21}$ The same analogy can be applied to Islamic banking. The Shari'a Supervisory Boards (ssbs) of individual banking institutions usually have considerable discretion in how they interpret shari'a rulings and may choose any school of Islamic jurisprudence to inform their decisions. However, since the different schools hold different views on key shari'a issues, this has created limitations for Islamic banking globally and has made Muslim investors nervous about buying Islamic finance products from outside their jurisdiction. ${ }^{22,23}$

These concerns have led to greater attention being paid in Islamic finance to standardisation. The debate on global standardisation has produced various arguments for and against this move. Muda and Jalil argue that standardisation is essential to circumventing the contradictions and inconsistencies between different fatwas and their application. ${ }^{24}$ Likewise, Ghoul states that the lack of

18 S. Haron \& N. Ahmad, 'The Islamic banking system in Malaysia: Some issues', in Proceedings of the Fourth Harvard University Forum on Islamic Finance -Islamic Finance: The Task Ahead (Cambridge, MA: Center for Middle Eastern Studies, Harvard University, 2011).

19 Ibid.

20 M.T. Usmani, 'The text of the historic judgment on interest given by the Supreme Court of Pakistan', 23 December 1999, accessed online on 1 April 2014 at www.albalagh.net/Islamic economics/riba_judgements.html.

21 Alwosabi, supra note 1.

22 Ibid.

23 Muda \& Jalil, supra note 11.

24 Ibid. 
standardisation across Islamic finance markets increases the risk that sharia is not complied with and that some contracts will not be recognised as valid under shari'a by all Islamic scholars. ${ }^{25}$

Some opponents of standardisation argue that forcing standardisation is contrary to the essence of Islam; others fear that a standardised application of sharica principles, by limiting innovation, would prohibit the development and growth of Islamic finance. Alwosabi lists Islamic finance's flexibility in allowing a broad variety of products to be tailored to each client's needs as one of its major strengths. The difference in opinion between the rulings of different shari'a boards is seen as an advantage in the sense that it brings about more innovation and creates room for new Islamic finance instruments. At the same time, he emphasises that the principles of shari'a cannot be compromised in providing solutions to clients' needs. ${ }^{26}$

Proponents of standardisation such as Ghoul argue that sharica scholars' lack of consensus has actually hampered innovation rather than encouraged it. $^{27}$ On a similar note, McKinsey's Global Head of Islamic Finance affirms that innovation will continue to take place once the basic standards are set. ${ }^{28}$ Hesse, Jobst and Sole suggest that a balance between collective initiatives and regulatory revisions will ensure that standardisation is achieved without negatively impacting financial innovation. ${ }^{29}$

Alwosabi and Azmi both mention that the absence of standardisation in sharica products may stifle the growth and integration of Islamic finance at both national and international levels.30,31 Domestically, Malaysia does not face this issue, because the Central Bank of Malaysia's Shariah Advisory Council acts as an authoritative body for Islamic finance practices within the country. However, internationally there are differences between Malaysia and other regions. This can create a problem for IFIs if they are subject to different standards, impacting on the efforts to increase their global presence and establish international operations. According to Hassan and Chowdhury, if the validity of products differs between countries practicing Islamic finance, it may

\footnotetext{
25 Ghoul, supra note 3.

26 Alwosabi, supra note 1.

27 Ghoul, supra note 3.

28 R. Wigglesworth, 'Sharia boards: Scholars hold sway over the success of products', Financial Times, 5 May 2009, accessed online on 1 April 2014, at http://www.ft.com/intl/ cms/s/o/91c1636e-3836-11de-9211-0o144feabdco.html.

29 H. Hesse, A. Jobst \& J. Solé, 'Trends and challenges in Islamic finance, world economics', The Journal of Current Economic Analysis and Policy 9(2) (2008): 175-193.

30 Alwosabi, supra note 1.

31 Azmi, supra note 2.
} 
expose IFIs to greater international risk. ${ }^{32}$ In addition, a lack of standardisation prevents investors from being aware of the exact risks they are assuming when they invest, increasing the costs of investment. ${ }^{33}$ Global standardisation could rectify these issues, as well as provide increased cross-border marketability for Malaysian IFIs.

As Hamad states, there are still too many loopholes, in terms of the practices, laws and regulations in Islamic finance. ${ }^{34}$ Garas observes, for instance, that Islamic banks record the same accounts differently: some banks treat mudàraba (a form of business contract in which one party contributes capital and the other personal effort) investment accounts as obligations; others treat them as fiduciary investments and accordingly report them as off-balancesheet accounts. To resolve these issues and facilitate international transactions, the reporting rules for IFIs will require a global standard. ${ }^{35}$ Hesse, Jobst and Solé suggest that efforts to consolidate regulatory frameworks and standards should address current issues such as the economic constraints and legal uncertainty created by variations in Islamic jurisprudence and the poorly developed uniformity of market practices. ${ }^{36}$

Mirakhor and Krichene emphasise that there is a pressing need to design, develop and implement 'a comprehensive, unified, uniform, global and dynamic regulatory-prudential-supervisory framework' so as to achieve financial stability. More important, they hold that such a framework should be uniquely and properly designed for Islamic finance. ${ }^{37}$ This challenge is considered to be particularly crucial in the context of Islamic finance as opposed to in the conventional financial system. McMillen argues that standardisation may never be achieved in an absolute sense. He proposes that a more realistic and realisable goal is a 'flexible codification of the Shariah principles and precepts', which will enable sufficient standardisation to allow effective interplay between Islamic markets. Further, he recommends that ongoing efforts to defragment Islamic

32 Hasan \& Chowdhury, supra note 5.

33 A. Shaharuddin, M.A.A. Mas'ad, Y.H.M. Safian, Z. Shafii, A.Z. Salleh, M.H. Alias, J.A. Seman, M. A. Laldin \& M.F.A. Khir, 'Fatwas on Islamic capital markets: A comparative study between Malaysia and Gulf Cooperation Council (GCC) countries', ISRA Research Papers 40 (2012): 1-36.

34 K. Hamad, 'Prospects and problems of shari'a compliant finance', in Islamic Finance Debate, Euromoney, December 2008, accessed online on 1 April 2014, at http://www .kantakji.com/media/163562/file834.pdf.

35 N.S. Garas, 'Internationalization of Islamic financial institution: Challenges and paths to solution', Thunderbird International Business Review 49(2) (2007): 225-249.

$36 \quad$ Hesse et al., supra note 29.

37 Mirakhor \& Krichene, supra note 7. 
markets and achieve some type of functional unification between Southeast Asian and Middle Eastern markets should be a primary concern. ${ }^{38}$

To achieve functional unification between Islamic markets, countries must converge, to some extent, in their interpretations of shari'a. This should lead to the creation of more homogeneous Islamic finance products and services and could, in turn, increase demand for and enhance the overall growth of the Islamic financial system. Greater convergence could also reduce some of the market inefficiencies caused by the heterogeneous prudential norms and interpretations of shari'a that have been discussed in the preceding sections. Thus, the next challenge for Malaysia in its attempts to achieve a global presence in the Islamic finance industry is to facilitate the convergence of regulatory and governance structures across national borders.

\section{$3 \quad$ Research Methods}

In our study, we used a qualitative approach, conducting interviews with industry experts to collect expert opinions. The rationale for using this method was to draw on the wide range of knowledge and experience held by industry practitioners and scholars.

We chose in-depth semi-structured interviews as a basis for the primary research, mainly because they give the respondent the freedom to express views and ideas in context. We used non-probability sampling, or more specifically, purposive sampling to select the group of experts interviewed. This was the most appropriate and viable sampling method with which to obtain the type of information required. The experts selected for the study are practitioners and academicians in Islamic banking and finance with extensive knowledge and experience in Islamic banking, financial regulation and standard setting and shari'a concepts of Islamic banking. The experts approached include researchers, Islamic bankers, sharía scholars, international standard setters, members of the top management of banks and academicians. The sample includes experts from the International Centre for Education in Islamic finance (INCEIF), ISRA, the Islamic Financial Services Board (IFSB), the Accounting and Auditing Organization for Islamic Financial Institutions (AAOIFI), the International Islamic University Malaysia (IIUM) and the Institute for Islamic Banking and Finance (IIBF), as well as members of the Central Bank of

38 M. McMillen, 'Islamic capital markets: Market developments and conceptual evolution in the first thirteen years', unpublished manuscript, 24 April 2011, online at: http://ssrn.com/ paper $=1781112$, accessed 6 August 2013 . 
Malaysia's Shariah Advisory Council and of international banks operating in Malaysia, such as Al-Rajhi Bank and Kuwait Finance House.

To achieve the research objectives and examine the relevant issues more deeply, this article poses the following research questions:

1. Is the implementation of unified global standards necessary to facilitate the internationalisation and global expansion of the Islamic finance industry?

2. What are the obstacles to formulating and implementing unified standards in Islamic finance?

3. Should a country like Malaysia adopt the same international standards as conventional finance or initiate a set of standards specifically designed to meet the requirements of globalised Islamic finance?

4. What are the major requirements of a unified framework for Islamic finance that will enable Malaysia or any other country to become a global platform for Islamic finance?

The interviews were collated and systemically analysed based on the major themes and issues that emerged to arrive at the findings of this research inquiry.

\section{$4 \quad$ Findings and Discussions}

The findings provided insights for all research questions. These insights will be discussed in relation to each research question.

\subsection{Is the Implementation of Unified Global Standards Necessary to Facilitate the Internationalisation and Global Expansion of the Islamic Finance Industry?}

With respect to the first research question, the experts can be placed into one of two camps. In the first camp are those who argue that such a move is not necessary. Industry practitioners from the Malaysian Islamic finance market observed that differences between jurisdictions had not posed any problems for the operation of international banks in Malaysia (such as Al-Rajhi and Kuwait Finance House). Some interviewees in this camp also argued differences in practices in Islamic finance mean that the failure of one set of practices does not result in the failure of the whole, so that the more robust set of practices prevails in the long term.

In the second camp are those who argue that the unification of standards is in fact very much required, specifically to reduce the differences in sharia 
interpretations and practices and avoid issues of regulatory arbitrage and sharica arbitrage or fatwa shopping, which are deemed to be the major impediments to globalisation and the international expansion of the Islamic finance industry. ${ }^{39}$ Further, the unification of standards could provide benefits for international trading. An international market where all parties were required to play by the same set of rules would facilitate market trading, which is important for the price discovery and liquidity requirements of Islamic finance. Thus, some interviewees in this camp proposed setting up a common platform whereby participants would be required to follow a common set of rules and standards, thus facilitating global trading in the Islamic financial markets, enhancing the competitiveness of Islamic financial markets in relation to conventional finance and reducing the regulatory and political risks that might otherwise arise in international markets.

This proposition is similar to the recommendation advanced by some IFIs that an international convention or platform be created in which each signatory party would agree to recognise the validity of any Islamic banking product recognised as valid in the jurisdiction in which it is issued, provided that the security is issued in a jurisdiction that is a party to the convention. As the IFIs have contended, a legal commitment to mutual recognition might also solve the problem of diverging domestic standards, without undermining the efficiency of cross-border Islamic financial flows. To some interviewees, these proposals - particularly the first one-constitute the highest level of harmonisation and may result in more globalised Islamic finance activities. Nonetheless, achieving such status—as they argue-requires preconditions. First, the establishment of such a platform should be preceded by closing the gaps in shari'a rulings among jurisdictions. Second, the crucial points of contention in the several regulatory, legal and governance frameworks must be identified, prioritised and resolved. Finally, the initiation of this international convention should be placed under the auspices of an international bodysuch as the Organisation of Islamic Co-operation (OIC) — and be supervised by international standards-setting bodies to ensure that countries with different standards and regulatory, legal and governance frameworks participate, hence overcoming or at least minimising the primary variations. If these preconditions are not satisfied, efforts to develop the Islamic finance industry will remain region-centric.

The proposals discussed so far assume convergence, but there is another view, one which presumes that at this stage of the Islamic finance industry's 
development convergence is impractical (for reasons we will address later in the article). According to this view, a model of Islamic banking regulation should instead be advanced that grants primary supervisory authority to the bank's home jurisdiction and then gives the foreign jurisdiction primary regulatory jurisdiction over the bank's operations in its territory (whether conducted through a branch of the home bank or as an independent subsidiary). This model aims at creating clear jurisdictional boundaries among various international banking regulators to mitigate the negative effects of different standards and frameworks in Islamic finance. Some interviewees asserted that this model is not applicable, as it would involve the intersection of several supervisory and regulatory issues, so forcing convergence would result in the stiffness in the development of Islamic finance markets. Besides, the differences in the maturity level of Islamic finance markets, the disparity in the infrastructure governing Islamic finance's development and the varying levels of the adoption of international standards among countries would generate different levels of playing field. Countries with less developed Islamic finance industries would find it difficult to comply with more sophisticated markets, hindering the model's operation in practice. Accordingly, some experts prefer determining specific domains or scopes which may create probable outlets to get over the divergence of jurisdictions and may be considered as a starting point to more connectivity. Some interviewees pointed out that this partial arrangement is practiced in Malaysia, where international operators such as Al-Rajhi Bank and Kuwait Finance House adhere to the resolutions of their main ssBs but comply with Malaysia's regulatory and supervisory frameworks.

\subsubsection{Form over Substance}

One of the issues that highlights the importance of robust global standards in Islamic finance is the debate regarding form over substance. The scholars interviewed stated that, in some Islamic finance transactions, it can be perceived that shari'a-compliance is only in 'form', while in substance the transaction is an exchange of money for money. Although the debate is ongoing, like the problems that can arise with commodity murābaha (Sale of goods with an agreed upon profit mark up on the cost) or bai' al-inah, it was observed that 'at this juncture in the development of Islamic finance, it is the only available alternative and we have to stay with it until we find another alternative' (interview). To rectify these issues, the interviewees argued, shari'a expertise has to play a greater role in ensuring that Islamic finance products are compliant with shari'a requirements, particularly in terms of how they are implemented. 

Standards in Islamic Finance?

In regard to the second research question, concerning the obstacles to formulating and implementing unified standards in Islamic finance, several issues were identified. First, it was observed that unifying Islamic finance standards would be difficult because Islamic jurisprudence allows flexibility in the interpretation of primary sources within the scope of sharica. Second, the experts felt that it would be challenging to agree on most issues in Islamic finance. However, the importance of arriving at common standards is paramount, they argued, as the current differences across jurisdictions are leading to inefficiencies in Islamic finance. Third, harmonising regulatory frameworks across jurisdictions would be complicated owing to the divergence in certain major segments of those frameworks. The most obvious aspect is the variance between common law and civil law. These are two distinct regimes, and the primary difference between them is trust law. The common law distinguishes between beneficial ownership and legal ownership; the civil law does not recognise such a distinction. This may somehow impair cross-border transactions. Sukuk issuance is the best example of this. Companies operating in a civil law jurisdiction may struggle to attract foreign investors due to there being no legal basis to create a special purpose vehicle (SPV), which is a common-law notion. Without the option of entering into an SPV, foreign investors would be exposed to very high levels of risk because so-called bankruptcy remoteness would not obtain, there being no transfer of the underlying asset subject to sukuk issuance to the legal title of the trustee (SPV) (i.e. the investors would not be protected).

The Maldives is a good example of this. It issued its first corporate sukuk in 2013, but it lacked SPV laws, trust formation laws, and bankruptcy declaration laws. ${ }^{40}$ To be more accurate, the then Companies Act did not contain provisions for SPVs. ${ }^{41}$ In addition, the country lacked laws governing trust. This provides a lacuna in protecting the rights of investors. ${ }^{42}$ The above-mentioned gaps would undoubtedly discourage foreign investors from investing in the Maldivian sukuk market.

Ultimately, regulators in the Maldives should develop trust law or at least find ways to align with it so as to create a more conducive regulatory framework

\footnotetext{
40 R. Wilson, Legal, Regulatory and Governance Issues in Islamic Finance (Edinburgh: Edinburgh University Press, 2012).

41 Securities \& Investments Institute Asia Pacific (SiiA), 'Developing a sukuk market in the Maldives: Final report, Australia 2011, accessed online on 1 April 2014 at http://www.cmda .gov.mv/assets/Special-Studies/Developing-Sukuk-Market-in-Maldives-2011-English.pdf. 
for sukuk issuance, enticing foreign participation and increasing cross-border transactions. The Maldivian case is not the only model of its kind, as the civil law jurisdiction exists in several countries around the world, so these issues would emerge anew. The experts noted that the stability of the Islamic financial system could be affected by inefficiencies caused by the complexity and opacity of Islamic finance instruments.

\subsubsection{Islamic Finance Industry Is Too Young to Impose Stricter Restrictions}

Several barriers that prevent the full implementation of standards issued by international standards-setting bodies were identified from the interviews, including the concern that the Islamic finance industry is still young, meaning it is too early to impose restrictions or stricter parameters. The varying development of the Islamic finance industry across countries was also identified as an obstacle to implementing unified standards. Malaysia, for instance, has a well-established market, but other countries' Islamic finance industries are at much earlier stages in their development. As a result, even if Malaysia were to implement international standards, countries with less developed IFIs would not have the capacity or the structures necessary to implement the same standards. The arguments against unified standards also include differences in local needs. There is a perception that unified standards would force one shari'a interpretation on everyone, which is a concern as there are varying shari'a interpretations.

Another key reason identified for the lack of adoption of international standards is that those standards have not yet been properly developed and are not revised and updated sufficiently often to keep up with the rapid changes in the industry. In addition, the international standards issued by the IFSB and other multilateral bodies such as the AAOIFI have no legal backing and are not mandatory-these bodies lack enforcement power. One of the implications that can arise from such practices is the differences in the implementation of some Islamic finance concepts which then result in legal disputes, as was the case of Blom Bank, a Lebanon-based bank, and the Investment Dar of Kuwait, a shari'a-compliant investment company. Wakäla (agency) was the concept governing the agreement between them. Blom Bank as the principal (muwakkil) nominated Investment Dar as its agent (wakil) to manage an investment amounting to USD 11.5 million. Investment Dar was bound by a clause in the agreement to pay an additional fixed return above the capital invested. Owing to the significant decrease in the value of its investments after the financial crisis of 2008, Investment Dar was unable to meet its financial obligations, and failed to pay the capital, not to mention the fixed return to Blom Bank. Hence, 
the latter sued Investment Dar and sought summary judgment to have the settlement amount repaid (i.e. the capital invested), in addition to the rate of return identified upfront. Investment Dar, to the surprise of its ssB, which had approved and validated the agreement, argued that it was not willing to pay its 'dues', as the contract was invalid and the anticipated profit determined at the outset was tantamount to interest and hence contravened the memorandum and article of association of the company. This created a conflict between Investment Dar's board of directors and its shari'a committee. ${ }^{43}$ Despite the court's resolution, which is not the concern of this article, the agreement is contradictory to the AAOIFI's standard number (23), paragraph (5/2), which proscribes the agent from indemnifying the principal for the invested asset in the event of damage or loss, unless the agent is negligent or breaches the terms and conditions of the contract, or the damage results from the agent's misconduct. Further, the standard expressly prohibits combining agency and guarantees in one contract because they are incompatible and to do so would turn the transaction into an interest-based loan, whereby the capital is guaranteed along with the return on the investment. ${ }^{44}$

This litigation is not the only controversial case of its kind. There are other cases, such as National Sukuk Company v. Al-Madina Finance and Investment Company and Islamic Investment Company of the Gulf v. Symphony Germs NV.45 The common denominator in these legal disputes is that they resulted from the lack of benchmark standardised contracts or the non-adherence of the contracting parties to the standards established by the aforementioned bodies.

Moreover, few central banks and individual institutions have voluntarily adopted these guidelines (for several reasons, such as nationalism and differences in governance systems and types of legal and regulatory frameworks between countries). As a result, international guidelines are not fully implemented, leading to regulatory issues being handled on a country-by-country basis. The abovementioned constraints on the unification of standards in Islamic finance are summarised in Table 1.

43 Wilson, supra note 40.

44 AAOIFI, Shariah Standards for Islamic Financial Institutions (Manama: Accounting and Auditing Organization of Islamic Financial Institutions, 2010).

45 E. Oz et al., 'Shari'ah non-compliance risk in the banking sector: Impact on capital adequacy framework of Islamic banks', IFs B Working Paper Series WP-03-05-2016, March 2016. 


\subsubsection{The Need for Unified Standards}

Despite these obstacles, a unified framework could solve the problem of fragmented markets and the region-centric growth of Islamic finance. Currently, financial activity, product innovation and regulatory developments are concentrated regionally, with significant differences between regions in practices, legislative and regulatory infrastructure and levels of development. Differences in regulatory and legal frameworks would prompt some contracting parties to agree in the so-called governing law clause that the agreement be governed, for instance, by English law. But to agree that a contract be governed by the laws of a foreign jurisdiction leads to two problems. First, it is not certain that courts would refer to shari'a principles in their rulings (English courts are commonly known to be creditor-friendly). Second, parties to a contract must decide on which foreign jurisdiction to place the contract under. The cases dealt with heretofore evidence that the English courts do not take into account shari'a in their decisions. To illustrate, the governing law clause of Shamil Bank in Bahrain EC v. Beximco Pharmaceuticals Ltd stated that: "Subject to the principles of the Glorious Shari'a, this agreement shall be governed and construed in accordance with the laws of England". In other words, English law would be the governing law in so far as it was not inconsistent with shari'a and, in

TABLE 1 Barriers to the implementation of international standards

It is too early in the development of the Islamic finance industry to impose strict restrictions or parameters.

Individual countries' Islamic finance industries are at different stages of development, so it is impractical to apply uniform regulatory standards.

Countries differ in their local requirements, constraints and preferences.

The standards set by international standards-setting bodies are not that well-developed.

A single shari'a interpretation might have to be followed by everyone, and there might be no allowance to resort to other shari'a interpretations. 
the event of any discrepancy, the sharia should prevail. ${ }^{46}$ However, the courts turned down Beximco counsel's claim that shari'a could be the governing law of the contract, because it was not the law of the country as stipulated in the Rome Convention (Article 1). Further, the courts refused the counsel's pretext that sharia could be included in the agreement by reference, as the English courts consider shari'a to be a religion, not a law. ${ }^{47}$ The same logic applies to the case of Blom Bank v. The Investment Dar Company explained above.

Another interesting case is the Dubai Islamic Bank PJSC v. PSI Energy Holding Co BSC and ORS. ${ }^{48}$ This case concerns the enforceability in English law of Islamic financial documents and security enforcements. ${ }^{49}$ In essence, the parties disputed which law should apply after the restructuration of the debt of which it was governed by English law-governed restructuring agreement (the "RSA") after the detection of commercial fraud committed by the abovementioned company. The dispute arose from the undertaking the defendants made to acquire an assignment (Assignment) for the benefit of the bank of a lease over some land in Dubai, land which had been procured using the proceeds of the original muräbaha financing agreement. ${ }^{50}$ The resultant conditional Assignment agreement was governed by UAE and Dubai law and subject to the exclusive jurisdiction of the Dubai courts. In addition, the Assignment stipulated that, in the event of a dispute between the RSA and the Assignment, the latter was to prevail. ${ }^{51}$ In November 2008, the bank accelerated the owed amounts pursuant to the default of Plantation Holdings (LZ) LLC under the RSA and enforced its security under the Assignment. The bank did not develop the land or sell the lease at that time, contending that, owing to the economic recession and the prevailing turmoil in the Dubai property market, the land was basically worthless or amounted to little value. The defendants thereafter claimed that the bank was at fault for failing to dispose of its interest in the lease and not realising some value. ${ }^{52}$

46 T.A.H. Mohammad \& A. Trakic, 'The adjudication of shari'ah issues in Islamic finance contracts: Guidance from Malaysia',Journal of Banking and Finance Law and Practice 26(1) (2015): 39-59.

47 International Sharía Research Academy \& Thomson Reuters (2016), Islamic Commercial Law Report, 130, online at https://ribh.files.wordpress.com/2007/08/isra-thomson-reuters -islamic-commercial-law-report-2016.pdf.

$48 \quad$ Ibid., 143 .

49 Ibid.

5o Ibid.

$51 \quad$ Ibid.

$5^{2} \quad$ Ibid. 
Expert evidence on behalf of the defendants (and in respect of UAE/Dubai law) proclaimed that the Assignment provided the bank with no right of ownership or possession, and thus the bank's appropriation of the lease by taking possession was usurpation under Dubai law, the effect of which was that the value of the lease at the time of such usurpation must be applied in diminution of the amounts due and owing under the RSA. ${ }^{53}$

English law, on the other hand, is guided by the principle that where a debt is governed by English law, the question whether or not the debt has been discharged is also a matter for English law. English law would not consider the bank as having taken possession of the land without having realised its value by sale as discharging the debt. The fact that a foreign law would consider the debt as discharged (and notwithstanding that the assignment itself was governed by UAE Dubai law) does not provide the debtor with a defence. Moreover, the RSA stipulated that the agreement was to be governed by and construed in accordance with English law, in so far as it is not discrepant with the principles of sharia law. Notwithstanding this, the judge ruled that this proviso was of no effect, as a religious law can never apply as the applicable law and so, in construing the RSA, shari'a was irrelevant. ${ }^{54}$

The point at issue in these cases is the legal basis upon which the courts build their resolutions, which may ultimately breach the core principles of Islamic finance. The contracting parties in cross-border transactions lack confidence on either regulatory framework to govern the contract and therefore opt mostly for English law to be the law of choice. Nevertheless, this option has created complex legal problems, as evidenced by Dubai Islamic Bank PJSC v. PSI Energy Holding Co BSC and ORS. In this context, the Central Bank of Malaysia's establishment of the Law Harmonisation Committee (LHC), which aims at harmonising different segments of law and shari'a, is an important step in constituting an appropriate legal framework, a framework that can become the law of choice and the preferred forum for settling cross-border Islamic financial transaction disputes. ${ }^{55}$

A more uniform growth of Islamic finance across the globe could be achieved if standards were unified. However, there is a gap in meeting this requirement due to the aforementioned constraints. One of the solutions proposed by the interviewees was that the Central Bank should implement the standards issued by the IFSB. However, shari'a scholars noted limitations in international standards, such as those of the IFSB and AAOIFI; further improvements are

\footnotetext{
$53 \quad$ Ibid., 58.

54 Ibid.

55 Central Bank of Malaysia, Law Harmonisation Committee Report, 2013.
} 
required to keep up with the evolving Islamic finance industry. Industry practitioners and standards setters noted that because the Islamic finance industry is at a nascent stage, it is too early to impose strict standards and so regulatory improvements and standardisation efforts should be slow and gradual.

Experts from standards-setting organisations noted that it was impractical for all countries to adopt the IFSB standards at the same time because of different levels of development in their respective Islamic finance industries. Countries such as Malaysia and Bahrain have more advanced Islamic finance industries, while others, like Brunei and Indonesia, are just beginning to establish Islamic finance industries. Some countries may therefore need to adopt international standards later than others.

Another issue is that the IFSB standards are not mandatory, serving only as guidelines for central banks; the IFSB does not have the power to enforce its guidelines. The body that does have the authority to enforce standards is the local authority or central bank of a country, not the international regulatory bodies. Thus, any changes in the regulatory structure of Islamic banking would be decided by the regulators in Malaysia or Bahrain rather than by the international standards setters.

\section{Should a Country Like Malaysia Adopt the Same International Standards as Conventional Finance or Initiate a Set of Standards Specifically Designed to Meet the Requirements of Globalised Islamic Finance?}

In response to the third research question two views were expressed. The first, held by the majority of the experts interviewed, was that many conventional standards and regulations also apply to Islamic finance and that it would therefore be reasonable to adopt them, amending specific articles to make them compatible with the principles of Islamic finance. The second view was that regulating Islamic finance would depend on the structure and form of Islamic finance being practiced. If Islamic finance continues to follow the same structure as conventional finance, then the present system will suffice, and the Bank of International Settlement (BIS) standards can be applied to Islamic finance. However, if Islamic finance moves away from debt-based financing towards a risk-sharing mechanism, which would be more in keeping with the fundamental principles of Islamic finance, then a distinct set of standards and regulations will need to be developed.

The Islamic finance scholars proposed several solutions to the problems identified. One of the short-term solutions was to move away from controversial products, for which there are differences of opinion regarding their 
shari'a-compliance (such as bai' al-inah), towards more widely accepted alternatives. Differences in enforcing international contracts could be effectively resolved through international arbitration at the Malaysian Regional Centre for Arbitration.

What Are the Major Requirements of a Unified Framework for Islamic Finance That Will Enable Malaysia or Any Other Country to Become a Global Platform for Islamic Finance?

Finally, in relation to the last research question, concerning the major requirements of a unified framework for Islamic finance that would enable Malaysia or any other country to become a global platform for Islamic finance, several points were identified. The prerequisites for a unified regulatory structure that would enable increased global activity in the Islamic finance markets, as identified from the findings of the primary research, are illustrated in Fig. 1.

The Islamic finance industry will be challenged to achieve global harmonisation and uniformity in the adoption, application and implementation of evolving standards for Islamic finance. Inconsistent application may result in confusion and the loss of clients' confidence in the principles of Islamic finance. For this reason, a universally accepted regulatory framework must be developed not only to support the industry's globalisation but also to foster its correct growth. Thus, one of the main requirements is to achieve regulatory consistency, through the harmonisation of shari'a governance standards, as well as integration with international regulations.

At the same time, the regulatory framework needs to be sufficiently flexible to cater to different local requirements and to allow for differences in shari'a interpretations. The goal of unifying standards is not to achieve complete homogeneity, as this would likely place limitations on the Islamic finance industry. However, the industry needs to resolve the fundamental concepts or issues that require commonality between jurisdictions, and to provide guidelines and restrictions on core issues, while leaving enough room for local requirements and financial innovation. To be effective, global standards will need to be made dynamic and responsive, so that they can address both local and global requirements.

One of the key regulatory requirements is the certainty and enforceability of shari'a contracts, not just locally but globally. This will require that a country's legal and regulatory framework is internationally recognised and accepted, and enforceable by a foreign court of law. However, this will require greater linkages and harmonisation across multiple legal jurisdictions and multinational contracting parties than are currently in place. 


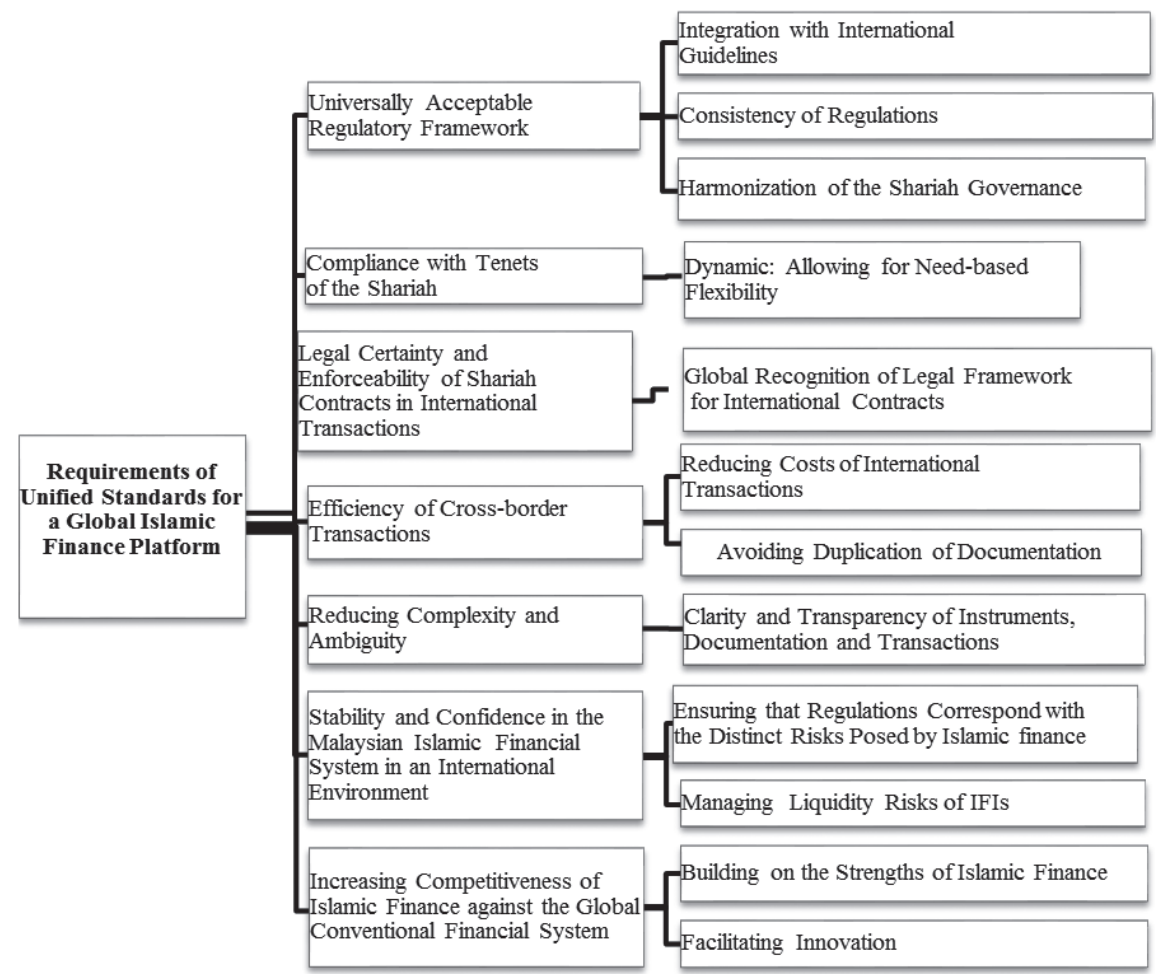

FIGURE 1 Requirements of a global Islamic finance platform

4.4.1 Differences of Interpretations of Islamic Principles

The biggest challenge for cross-border transactions in Islamic finance is the differences in the schools of Islamic jurisprudence and the diversity of interpretations of Islamic principles. To solve this problem, the Islamic finance industry must harmonise shari'a rulings across jurisdictions and arrive at mutual recognition of different products. However, harmonisation may require the establishment of a single shari'a authority to come to integrated, globally recognised and accepted shari'a decisions. In addition, enforcing the standards issued by such a shari'a authority will require mechanisms to be set up for a shari'a-compliance and governance system that can apply to and be accepted by all foreign participants in the Islamic financial markets.

\subsubsection{The Need for Effective Shari'a Arbitration}

In addition to harmonisation, an effective arbitration mechanism is one of the solutions proposed to facilitate agreements to be reached on any differences 
that may arise in shari'a matters. A sound mechanism for the resolution of shari'a compliance matters is necessary because regulators are not always in a position to resolve these issues. Additionally, standardising documentation and contracts could reduce the need to resort to shari'a arbitration. This would enhance the clarity and transparency of Islamic financial instruments, transactions and documentation, while avoiding any issues of duplication and higher costs that may otherwise be associated with international transactions. Documentation and contracts that are accepted worldwide not only will increase enforceability of the standard but also will give greater confidence to clients.

Proper standardisation of financial instruments and documentation must be achieved so that the products offered are common instruments acceptable to all schools of Islamic jurisprudence. There is sufficient room to identify the aspects that are common to all jurisdictions, and to design products that are acceptable across all schools and views. The development of widely accepted products and services is a challenge that has to be taken on by Malaysia's bankers and shari'a scholars, as it will be critical to removing the confusion, complexity and ambiguity in Islamic finance. The first step in this direction will be to achieve harmonisation of the core concepts of Islamic finance.

The importance of unification and harmonisation of Islamic finance practices between jurisdictions lies in the fact that they will enable financial transactions to be conducted in a common global market. A global platform for Islamic finance will require stronger risk management measures, including the provision of adequate liquidity management for IFIs. Although the International Islamic Liquidity Management Corporation has been set up for this purpose, it is still relatively new, with only one sukuk issuance to date. Malaysia, for example, has a well-established money market and capital market, as well as a full secondary market, so it can provide liquidity management to global IFIs.

4.4.3 The Need for Government Support for Islamic Finance

To be a global platform for Islamic finance, a country needs full backing and support from government. Malaysia, for instance, has made more progress than other jurisdictions in developing the infrastructure, legislation and regulation necessary for Islamic finance. It is already a leading country in Islamic finance, with an established National Shari'a Council, so it could become a global authority in Islamic finance regulation. It could provide reference laws and guidelines for global Islamic finance transactions and provide also the requisite infrastructure, as well as an international market, for the globalisation of 
Islamic finance. However, this would require Malaysia not only to have a solid and robust legal and regulatory framework but also to further fine-tune this framework to make it more applicable to other jurisdictions (and more acceptable them). The success and viability of the proposed solutions will depend on ensuring that the regulatory system focuses on maintaining financial stability. Regarding how the authorities should go about regulating Islamic finance so as to maintain its stability, two conclusions can be derived from the findings.

First, even though contracts are different under Islamic finance and require different forms of risk governance, both conventional and Islamic financial institutions are exposed to similar risks (e.g. credit, market, liquidity and operational risks). Due to this, the reforms under Basel III, which aimed at strengthening capital and liquidity buffers (i.e. the prudential guidelines issued by the BIS), can be applied to IFIS, as suggested by the majority of the interviewed experts. The universal implementation of these international guidelines may be necessary to avoid regulatory arbitrage or any form of competitive distortion that might arise. Since the IFSB has adapted the Basel III guidelines to suit Islamic finance, one of the potential solutions to this issue would be to make adopting the IFSB standards mandatory.

Second, the regulatory regime should incentivise stronger adherence to shari'a principles so that the Islamic financial system can provide the financial stability lacking in the conventional financial system. Therefore, additional regulation to augment the BIS or IFSB guidelines is required for Islamic finance. Such regulation also needs to be specifically formulated for equitybased or risk-sharing transactions. This regulatory structure not only will provide a greater incentive to increase the proportion of risk-sharing transactions but also will make Islamic finance more stable than conventional finance by reducing its reliance on a debt-based structure. Thus, one of the regulatory requirements will be to ensure that the regulatory framework allows sufficient risk-sharing in the Islamic financial system. To put this into effect, a robust unified framework that will enable increased global risk-sharing is needed.

Additionally, there has to be a more precise distinction between Islamic finance and conventional finance in terms of their prudential and financial reporting requirements, to reflect the differences in their natures and risk profiles. In particular, the prudential and reporting framework should reflect the risks faced under risk-sharing arrangements in Islamic finance. Although certain general regulatory principles and standards can be applied to both Islamic and conventional finance transactions, a blanket application of these rules to Islamic finance would limit the implementation of risk-sharing contracts. That is why the regulatory framework for Islamic finance must be appropriately 


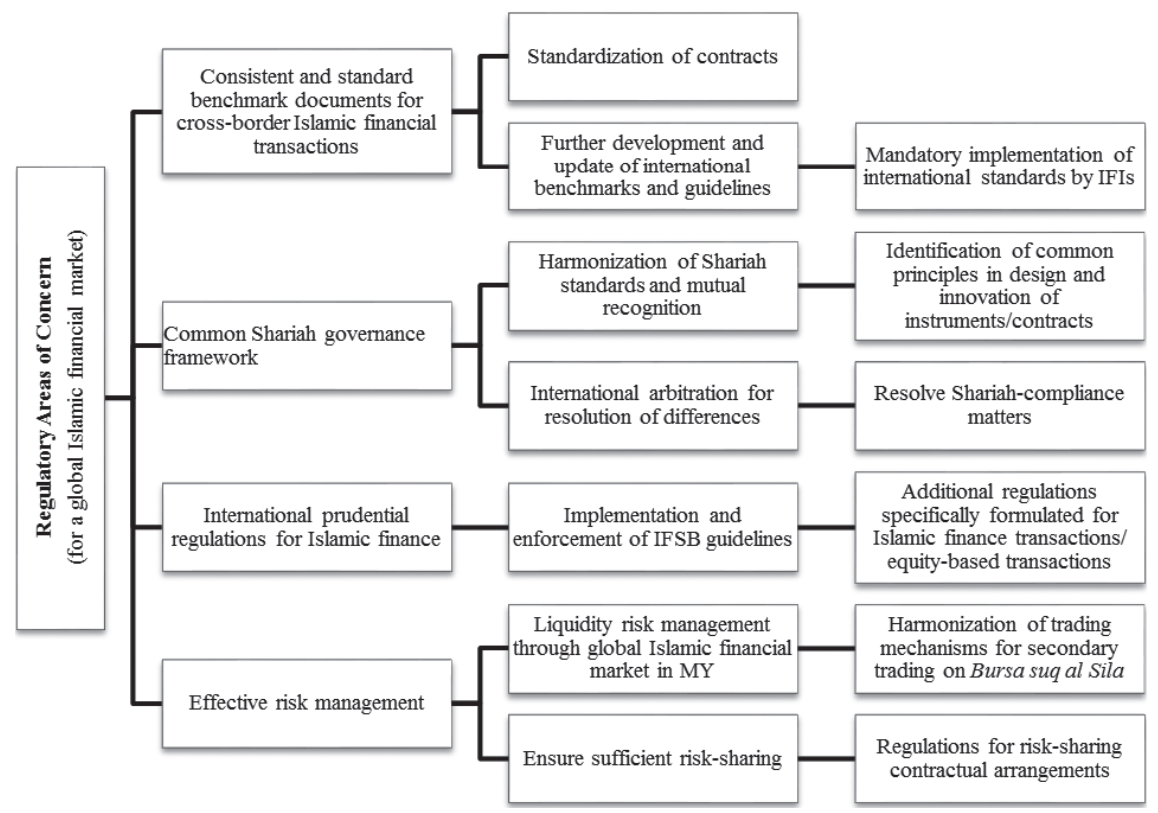

FIGURE 2 Regulatory areas of concern that need to be addressed by relevant authorities

designed for the risks that are unique to it. In addition to the international standards with which both Islamic and conventional banks have to comply (such as the BIs guidelines), evolving guidance on regulatory standards must be aimed at the specific characteristics of Islamic finance.

Based on the above discussions, Fig. 2 summarises the key areas that need to be addressed. Addressing these above areas will enhance the effectiveness, transparency and robustness of the standards, which will instil confidence in customers and eliminate any loopholes in cross-border contracts. The objective of unifying the standards is not to have absolute homogeneity across jurisdictions but to arrive at a common framework acceptable to all jurisdictions and flexible enough to accommodate local requirements. International standards must be implemented in Malaysia (or any other country) to enhance the global platforms that already exist, such as BSAS, and further open up the Islamic finance industry to international markets, making regulatory practices and contracts in countries with more developed Islamic finance industries transferable to countries with Islamic finance industries still in their early stages. 
The proposed unified regulatory framework faces many constraints and requires further development and the maturity of the industry. The stage and level of development of the Islamic financial system has to be taken into consideration to ensure that the application of global standards and the unification of regulatory frameworks can be achieved without any unintended consequences, given the present constraints. There is some reluctance about the concept of unification itself, mainly due to the different views that are an inherent part of Islamic finance.

There are several obstacles to the implementation of standardised international benchmarks for Islamic finance. First, there are differences in legal frameworks between jurisdictions, as well as differences in the level of strictness applied in the shari'a-compliance requirements. Second, the Islamic finance industry is at varying stages of development in different countries. Some countries are more advanced, while others are just starting out and thus lack proper legal and regulatory frameworks. The onus is on countries such as Malaysia, which are at a more advanced stage, to establish and implement international benchmarks or standards that will set a precedent for other countries.

In addition, the prevalent opinion towards the regulation of Islamic finance is that it is acceptable to retain most of the aspects of the conventional regulations that do not contradict the sharica, and to make modifications to any specific articles that might contradict the sharica. The most prevalent view is that this approach will be suitable for the time being. However, it is important to reassess the more fundamental questions of what Islamic finance is about, where it should be headed, and how this can be achieved. If Islamic finance were to move towards a greater risk-sharing model, it would require regulatory and supervisory processes that are very different from those in conventional finance. Further changes and amendments may have to be made to the regulatory guidelines if Islamic finance moves in a different trajectory to conventional finance in terms of its structure and function. The same regulatory structure cannot be used for a risk-sharing system, since the current financial regulatory system is fundamentally designed to cater for the risk transfer and risk shifting that goes on within conventional finance.

In order to resolve the question of regulation, it is first necessary to determine a common model of Islamic finance. It would be difficult for Islamic banking to compete with the conventional sector by replicating the conventional model. If Islamic finance follows the conventional model, it will become less competitive because it will be exposed to the same risks and instability faced by the conventional system. Moreover, the conventional model adapted 
to the Islamic situation would still create the same problems for Islamic banking as it does for conventional banking. So from the perspective of developing a stable global Islamic financial system, the industry has to look towards building a proper system or model for Islamic finance that will be Islamic in essence, and will provide the benefits that the Islamic approach offers. This will eventually make the approach more competitive within the global market against the conventional banks. Determining what this Islamic model should look like is a necessary part of assessing the specific requirements for the regulation of Islamic finance.

If Islamic finance is to be globalised, and if cross-border operations are to be established, countries must develop a uniform regulatory and legal framework for the Islamic finance industry. This will enable the Islamic market in Malaysia, or in any other country, to interact or be linked together with international markets without facing regulatory, legal or political risks. It is particularly important that a global Islamic financial market is developed so that it will facilitate price discovery, and so that Islam-derived prices and benchmarks can be used instead of conventional benchmarks. First, the risks of conventional financial systems must not be transferred to IFIs. Second, it is essential for the further progress and growth of Islamic finance, because Islamic banks will otherwise remain followers of and be overshadowed by conventional institutions.

Malaysia, for example, benefits from established institutional structures and government support for the development of Islamic banking and finance. It has the potential to establish a fully-fledged Islamic financial system that can be replicated by other Muslim countries. The implementation of more unified regulatory and shari'a compliance structures will enable the developments occurring in Malaysia to be transferred to countries with less developed Islamic banking systems. Having one of the most developed domestic regulatory and legal frameworks for Islamic finance; Malaysia should take the lead in helping to create a standardised regulatory and supervisory framework worldwide.

Based on the overall solutions proposed in this article, the following policy recommendations can be made. First, harmonisation can be bolstered by developing more interfaces between regulators and other central banks. Establishing a cooperative and systemic alliance between central banks will help in coordinating the development of standards, supervising compliance with those standards and enforcing them. The Central Bank of Malaysia can work with Islamic scholars and other central banks to reach a flexible and shared, if not unified, understanding of the fundamental principles at the international level. Developing a unified code of practice and aligning industry stakeholder practices will require effective and continuous dialogue with other jurisdictions to reach an understanding on banking regulation and supervision. 
In addition, Islamic financial contracts and documentation must, gradually, be standardised. Scholars of the different schools of Islamic jurisprudence must reach a consensus for shared or harmonised guidance, to develop a more unified institutional mechanism for the adoption of common sharia standards on key concepts and to ensure proper enforcement through effective controls. A holistic approach must be taken to look at the overall issues and goals of Islamic finance (rather than the case-by-case approach used in the past) so as to identify and align strategies that will enable Malaysia, as a leader in the industry, to formulate, revise and enforce a harmonised and standardised set of best practices together with other regional leaders in Islamic finance (e.g. Bahrain). Such an approach should include the development of a comprehensive unified code of practice that addresses the different regulatory, legal and shari'a parameters needed to govern and regulate the global platform.

Furthermore, further developments and improvements should be made to the Islamic financial system's accounting procedures and standards. In particular, human capital must be developed if progress is to be made in Islamic finance. Most important, cooperation with other jurisdictions to develop, adopt and enforce uniform regulatory and tax frameworks will ensure that all jurisdictions are moving in the same direction.

The evolution of a single, unified regulatory framework for the Islamic financial services industry should be encouraged to help regulators to overcome their current difficulties. It is also important not to compromise the flexibility of the shariaa, because it is a major strength for Islamic finance, in that it allows a wider variety of products to be tailored to varying needs. In this sense, the unavoidable differences in shari'a rulings may be beneficial in providing solutions to product innovation requirements and meeting the needs of Islamic finance. However, in the process of providing solutions, care has to be taken to avoid compromising the basic principles of shari'a. In this regard, a commonly mandated set of standards, followed by all foreign and local participants in Islamic finance market, will ensure that financial institutions remain dynamic but do not compromise Islamic principles.

Common regulations could also make the resulting standards more stringent and robust. Unifying standards could enable Muslim countries to accrue greater benefits from the globalisation of the Islamic financial sector and attract more foreign direct investment and portfolio equity flows. It could also enable greater integration of the Islamic financial markets, increase the diversification opportunities and expand the set of available financial instruments, which could increase the volume of two-way investments. It also has the potential to enable increased global risk-sharing, which would allow a movement towards a more ideal risk-sharing structure for Islamic finance. 